\title{
A narrative review on environmental impacts of cannabis cultivation
}

\author{
Zhonghua Zheng ${ }^{1}$, Kelsey Fiddes ${ }^{2}$ and Liangcheng Yang ${ }^{2^{*}}$ (D)
}

\begin{abstract}
Interest in growing cannabis for medical and recreational purposes is increasing worldwide. This study reviews the environmental impacts of cannabis cultivation. Results show that both indoor and outdoor cannabis growing is water-intensive. The high water demand leads to water pollution and diversion, which could negatively affect the ecosystem. Studies found out that cannabis plants emit a significant amount of biogenic volatile organic compounds, which could cause indoor air quality issues. Indoor cannabis cultivation is energy-consuming, mainly due to heating, ventilation, air conditioning, and lighting. Energy consumption leads to greenhouse gas emissions. Cannabis cultivation could directly contribute to soil erosion. Meanwhile, cannabis plants have the ability to absorb and store heavy metals. It is envisioned that technologies such as precision irrigation could reduce water use, and application of tools such as life cycle analysis would advance understanding of the environmental impacts of cannabis cultivation.
\end{abstract}

Keywords: Cannabis cultivation, Water demand, BVOCs emission, Carbon footprint, Soil erosion

\section{Background}

TheCannabis plant has been cultivated throughout the world since ancient civilizations and used for thousands of years for both medicinal and recreational applications. Cannabis contains a psychoactive compound called tetrahydrocannabinols (THC) that creates a psychogenic effect. It can be consumed through the respiratory tract and digestive tract through smoking and oral ingesting, respectively. In contrast, cannabidiol (CBD), another component derived from cannabis, is a non-psychoactive cannabinoid that has gained popularity for its medicinal values and as a supplement. In the USA, an estimated "30 million Americans use marijuana (cannabis) at least occasionally, and 20 million use it at least once per month" (Osbeck and Bromberg 2017). Despite being used widely, the lack of science-based information due to the legal status of cannabis in the last centuries worldwide (e.g., in the USA) has prevented research.

\footnotetext{
*Correspondence: lyang@ilstu.edu

${ }^{2}$ Department of Health Sciences Environmental Health and Sustainability Program, Illinois State University, Normal, IL 61790, USA

Full list of author information is available at the end of the article
}

Cultivation methods have an unavoidable influence on the environment in different degrees. Outdoor cultivation is the traditional and original method of cannabis cultivation. Although with low costs, it is subject to weather and natural resources. Improper soil and water resources management and pest control may induce critical environmental issues. On the contrary, indoor cultivation (including greenhouse cultivation) enables full control over all aspects of the plants, such as light and temperature, but is constrained by higher costs, energy demand, and associated environmental implications. Reducing the global environmental impact of agriculture is vital to maintain environmental sustainability. However, there is a lack of systemic principles towards the sustainable farming of cannabis because its environmental impacts remain unclear. In the wake of the unprecedented legalization of cannabis, there is a pressing need for a complete review of its environmental assessment.

In this paper, we conduct a narrative review of the available literature. We strive to build a better understanding of the environmental impacts induced by cannabis cultivation. This improved understanding can benefit communities, including policymakers, cannabis industry original author(s) and the source, provide a link to the Creative Commons licence, and indicate if changes were made. The images or other third party material in this article are included in the article's Creative Commons licence, unless indicated otherwise in a credit line to the material. If material is not included in the article's Creative Commons licence and your intended use is not permitted by statutory regulation or exceeds the permitted use, you will need to obtain permission directly from the copyright holder. To view a copy of this licence, visit http://creativecommons.org/licenses/by/4.0/. 
stakeholders, agricultural engineers, ecologists, and environmental scientists. This review covers the environmental effects on water, air, and soil. Energy consumption and carbon footprint are included as well. Possible research directions are also put forward.

\section{Methods and materials}

The literature search for this narrative review paper was conducted several times in 2020 and 2021. We searched combinations of keywords such as "cannabis cultivation," "marijuana cultivation," "cannabis water demand," "cannabis emissions," "cannabis energy demand", and "environmental impacts." Papers, reports, and government documents from 1973 to 2021 from Science Direct and Google Scholar databases have been searched in English. We screened over 250 literatures and discarded irrelevant literature for further analysis. A total of 63 literatures were cited in the review.

\section{Water demand analysis}

To unify the water demand calculations from different data sources, we conducted the following unit conversions:

1 inch of water $=27,154$ gallons of water per acre

$$
1 \text { acre }=43,560 \mathrm{ft}^{2}
$$

Similarly, units reported for water demand such as "mm/total growing period" were converted to "gallon/ $\mathrm{ft}^{2} /$ day". For example, the water need of cotton is $700 \mathrm{~mm}$ per total growing period. The water demand was calculated to:

$$
700 \mathrm{~mm}=27.56 \text { inches }=748,346 \text { gallon per acre }
$$

Finally, the minimal daily water demand for cotton (shown in Table 1) was calculated using the maximal growing days (195 days):

$$
\frac{748,346 \text { gallon per acre }}{195 \text { days }} \times \frac{\text { acre }}{43,560 \mathrm{ft}^{2}}=0.09 \frac{\text { gallons }}{\mathrm{ft}^{2} \times \text { days }}
$$

\section{Water demand and pollution Water demand}

Cannabis is a water- and nutrient-intensive crop (Carah et al. 2015). Table 1 shows that the water demand for cannabis growing far exceeds the water needs of many commodity crops. For example, cannabis in a growing season needs twice as much as the water required by maize, soybean, and wheat. On average, a cannabis plant is estimated to consume 22.71 (6 gallons) of water per day during the growing season, which typically ranges from June to October for an approximate total of 150 days (Butsic and Brenner 2016). As a comparison, the mean water usage for the wine grapes, the other major irrigated crop in the same region, was estimated as 12.64 l of water per day (Bauer et al. 2015).

\begin{tabular}{|c|c|c|c|c|}
\hline Plants & $\begin{array}{l}\text { Total growing period } \\
\text { (days) }\end{array}$ & $\begin{array}{l}\text { Water demand per } \\
\text { season } \\
\text { (million gallons acre }{ }^{-1} \text { ) }\end{array}$ & $\begin{array}{l}\text { Daily water demand } \\
\left(\text { gallon }^{-2} \text { day }^{-1}\right)\end{array}$ & Ref \\
\hline Cannabis: outdoor & 150 & $1.57^{\mathrm{a}}$ & 0.24 & (HGA, 2010) \\
\hline Cannabis: outdoor & August & n.a & 0.22 & (Wilson et al., 2019) \\
\hline Cannabis: outdoor & September & n.a & 0.17 & (Wilson et al., 2019) \\
\hline Cannabis: indoor & August & n.a & 0.18 & (Wilson et al., 2019) \\
\hline Cannabis: indoor & September & n.a & 0.22 & (Wilson et al., 2019) \\
\hline Cotton & 180-195 & $0.75-1.39^{b}$ & $0.09-0.15$ & (Brouwer and Heibloem, 1986) \\
\hline Cotton & / & / & $0.14-0.17$ & (Hussain et al., 2020) \\
\hline Maize & $130-150$ & $0.53-0.86^{b}$ & $0.07-0.13$ & (Brouwer and Heibloem, 1986) \\
\hline Corn & / & / & 0.22 (peak) & (Rogers et al. 2017) \\
\hline Soybean & $135-150$ & $0.48-0.75^{b}$ & $0.07-0.13$ & (Brouwer and Heibloem, 1986) \\
\hline Soybean & / & / & 0.22 (peak) & (Rogers et al. 2017) \\
\hline Wheat & $120-150$ & $0.48-0.69^{b}$ & $0.07-0.19$ & (Brouwer and Heibloem, 1986) \\
\hline Wheat & / & / & 0.19 (peak) & (Rogers et al. 2017) \\
\hline Rice & $90-150$ & $0.48-0.75^{b}$ & $0.09-0.18$ & (Brouwer and Heibloem, 1986) \\
\hline Rice & / & / & $0.11-0.15$ & (Intaboot, 2017) \\
\hline
\end{tabular}
Although the average daily water use varies from site

Table 1 Water demand comparison between Cannabis and commodity crops

Note ${ }^{\mathrm{a}}$ : The water demand of cannabis is calculated based on 22.7 I (6 gallons) of water per day during the growing season and 200 plants per 5,000 sq. $\mathrm{ft}$ (HGA, 2010) Note $^{\mathrm{b}}$ : The water demand of crops is based on crop water need from Table 14 in Brouwer Heibloem (Brouwer and Heibloem, 1986). We convert the unit from mm to million gallon acre $^{-1}$ according to the rule of unit conversion where 1 acre inch is equivalent to $27,154.29$ gallon 
to site, depending on many factors such as the geographic characters, soil properties, weather, and cultivation types, it is an agreed-upon truth that cannabis is a high-use water plant. A survey conducted by Wilson et al. (2019) reports the water usage of outdoor cannabis cultivation in California is 5.5 gallons per day per plant (equivalent to 0.22 gallon $\mathrm{ft}^{-2}$ day $^{-1}$ ) in August and 5.1 gallons per day per plant (equivalent to 0.17 gallon $\mathrm{ft}^{-2} \mathrm{day}^{-1}$ ) in September (Wilson et al. 2019). The indoor cultivation water consumptions are 2.5 and 2.8 gallons per day per plant in August and September. However, the application rates $\left(0.18\right.$ gallon $\mathrm{ft}^{-2}$ day $^{-1}$ in August and 0.22 gallon $\mathrm{ft}^{-2}$ day $^{-1}$ in September) are very close to outdoor cultivation (Wilson et al. 2019). In California, irrigated agriculture is regarded as the single largest water consumer, accounting for $70-80 \%$ of stored surface water and pumping vast volumes of groundwater (Moyle 2002; Bauer et al. 2015). The great water demand induced by agriculture, amid population growth and climate change, is most likely to exacerbate water scarcity in the foreseeable future (Bauer et al. 2015). Notably, the predicted decrease in water availability downscales in California may adversely affect the value of farmland (Schlenker et al. 2007) and pose a severe challenge to the cannabis industry. As a result, the immense amount of water necessary to keep cannabis plants alive and healthy will continue to burden our environment.

The high water demand presses the need for water sources. Water diversion is a common practice, which removes or transfers the water from one watershed to another to meet irrigation requirements. While the water diversion alleviates the water shortage problem for cannabis cultivation, it also presents new challenges. A study conducted by Bauer et al. quantitatively revealed that surface water diversions for irrigation led to reduced flows and dewatered streams (Bauer et al. 2015). Four northwestern California watersheds were investigated in this study since they are remote, primarily forested, sparsely populated. The results show that the annual seven-day low flow was reduced by up to $23 \%$ in the least impacted watersheds of this study, and water demands for cannabis cultivation in three watersheds exceed streamflow during the low-flow period. More recently, Dillis et al. identified well water $(58.2 \%)$, surface water diversions (21.6\%), and spring diversions (16.2\%), are the most commonly extracted water source for cannabis cultivation in the North Coast region of California (Dillis et al. 2019). The distributing percentages, however, vary among the counties. For example, the growers in Humboldt County relied more on surface water and spring diversions (57\%) than the wells $(40.9 \%)$, while another study conducted by Wilson et al. showed that groundwater (wells or springs) was the primary water source for irrigation, followed by municipal water, rainwater, and surface water (Wilson et al. 2019).

\section{Water pollution}

Cannabis cultivation, especially illegal cultivation, may deteriorate water quality. Recent studies have suggested the considerable demands of nutrition such as nitrogen (Saloner and Bernstein 2020, 2021), phosphorous (Shiponi and Bernstein 2021), and potassium (Saloner et al. 2019) for cannabis growth. However, there is limited data on the impact of cannabis cultivation on water quality worldwide or even nationwide. Here we focus on a survey conducted by Wilson et al. (2019) for CA, USA. Based on the survey, more than 30 different soil amendments and foliar nutrient sprays were used to maintain nutrition and fertility (Wilson et al. 2019). The applied pesticides (including herbicides, insecticides, fungicides, nematodes, and rodenticides), due to routine pest and disease controls, make their way into the water without restriction and therefore posing significant risks to the water environment (Gabriel et al. 2013). The transport and fate of the applied fertilizers and pesticides vary. For example, nitrogen and pesticides can get into runoff or leach into groundwater due to rainfall or excessive irrigation (Trautmann et al. 2012). If the polluted water continues to be used, it would add contaminants into soil, surface water, and groundwater. These chemicals may threaten humans and crops through the food chain (Pimentel and Edwards 1982). The other major irrigated crops can also be significantly impacted since the placement of crops is subject to the environmental safety of runoff, groundwater contamination, and the poisoning of nearby bodies of water. However, without the ability to sample water quality and assess the extent to which chemical inputs are entering adjacent water bodies, the ability to link cultivation practices to water pollution is greatly limited (Gianotti et al. 2017). Besides, few environmental clean-up and remediation efforts in the polluted watersheds are accessible due to a lack of resources and staff in state or federal agencies.

\section{Water ecosystem}

Water diversion and water pollution affect the water ecosystem. The high demand for water due to cannabis cultivation in watersheds affects wildlife such as fish and amphibians in a significant way since cannabis cultivation is widespread within the boundaries of the watersheds, where the downstream water houses populations of sensitive aquatic species. The diminished flows may be notably detrimental to salmonid fishes since they need clean, cold water and suitable flow regimes (Bauer et al. 2015). As the reduced streamflow has a strong positive 
correlation with increased water temperature, indirectly resulting in reduced growth rates in salmonids, lowered dissolved oxygen, increased predation risk, and increased susceptibility to disease (Marine and Cech 2004). It has been reported that there are $80 \%-116 \%$ increases in cannabis cultivation sites near high-quality habitats for threatened and endangered salmonid fish species (Butsic et al. 2018). Besides, the threat of water diversions and altered stream flows to amphibians cannot be neglected. The desiccation-intolerant species, such as southern torrent salamander (Rhyacotriton variegatus) and coastal tailed frog (Ascaphus truei), are vulnerable to headwater stream diversions or dewatering (Bauer et al. 2015). The headwater stream-dwelling amphibians also exhibit high sensitivity to water temperature changes (Bury 2008). It is vital to get all the growers on the same page regarding water resources because flow modification is one of the greatest threats to aquatic biodiversity. The cannabis industry is becoming a major abuser concerning water diversions. Studies show that the second-generation anticoagulant rodenticides (ARs) affect many predators in both rural and urban settings (Gabriel et al. 2013, 2012; Elliott et al. 2014). Necropsy revealed that a male fisher had died of acute AR poisoning in April 2009, most likely due to the source of numerous illegal cannabis cultivation sites currently found on public lands throughout the western USA (Thompson et al. 2014). A study examining the effects of Ars on the Pacific fisher reports that four out of fifty-eight deceased fishers examined were killed by "lethal toxicosis, indicated by AR exposure."

\section{Outdoor and indoor air quality Outdoor air quality}

Little attention has been devoted so far to study the impact of cannabis cultivation on outdoor air quality. The emission of volatile organic compounds (VOCs) attracts special attention because of the vital role played by VOCs in ozone and particulate matter formation, as well as VOC's health impact (D.R. et al. 2001; Jacob 1999). Amongst the VOCs, the biogenic volatile organic compounds (BVOCs) (Atkinson and Arey 2003), mainly emitted from vegetation, account for approximately $89 \%$ of the total atmospheric VOCs (Goldstein and Galbally 2007). Previous studies have identified cannabis plant tissues contain high concentrations of many BVOCs such as monoterpenes $\left(\mathrm{C}_{6} \mathrm{H}_{16}\right)$, terpenoid compounds (e.g., eucalyptol; $\left.\mathrm{C}_{10} \mathrm{H}_{18} \mathrm{O}\right)$, sesquiterpenes $\left(\mathrm{C}_{15} \mathrm{H}_{24}\right)$, and methanol. Hood et al. investigated that the monoterpenes $\alpha$-pinene, $\beta$-pinene, $\beta$-myrcene, and $d$-limonene accounted for over $85 \%$ of the detected VOCs emitted, with acetone and methanol contributing a further 10\% (Hood et al. 1973; Rice and Koziel 2015; Ross and ElSohly 1996). However, limited systematic studies characterized and accurately quantified volatile emissions during the growing and budding process (Wang et al. 2019b).

To determine the BVOCs emission rates, Wang et al. employed an enclosure chamber and live Cannabis spp. plants during a 90-day growing period considering four different strains of Cannabis spp. including Critical Mass, Lemon Wheel, Elephant Purple, and Rockstar Kush (Wang et al. 2019b). They found the percentages of individual BVOCs emissions were dominated by $\beta$-myrcene (18-60\%), eucalyptol (17-38\%), and d-limonene (3-10\%) for all strains during peak growth (Table 2). The terpene emission capacity was determined, ranging from 4.9 to $8.7 \mu \mathrm{g}$-C per g dry biomass per hour. The estimation with $\mu \mathrm{g}-\mathrm{C}$ per $\mathrm{g}$ dry biomass per hour for Denver would result in more than double the existing rate of BVOCs emissions to 520 metric ton year ${ }^{-1}$, leading to 2100 metric ton year ${ }^{-1}$ of ozone, and 131 metric ton year ${ }^{-1}$ of PM (particular matter). However, a high emission can be expected since the better growing conditions contribute to rapid growth and higher biomass yields.

A recent study conducted by Wang et al. was the first attempt at developing an emission inventory for cannabis (Wang et al., 2019a). This study compiled a bottom-up emission inventory of BVOCs from cannabis cultivation facilities (CCFs) in Colorado using the best available information. Scenarios analysis shows that the highest emissions of terpenes occur in Denver County, with rates ranging from 36 to $362 t$ year ${ }^{-1}$, contributing to more than half of the emissions across Colorado. With the emission inventory, the air quality simulations using the Comprehensive Air Quality Model with extensions (CAMx) show that increments in terpene concentrations could results in an increase of up to $0.34 \mathrm{ppb}$ in hourly

Table 2 Composition of BVOCs

\begin{tabular}{lll}
\hline BVOCs & 30-day (\%) & 46-day (\%) \\
\hline B-myrcene & $26.6-42.6$ & $18.3-59.4$ \\
Eucalyptol & $18.5-32.8$ & $16.8-37.6$ \\
d-limonene & $4.4-17.2$ & $3.0-10.0$ \\
p-cymene & $2.3-12.8$ & $0.6-4.6$ \\
Y-terpinene & $2.0-9.7$ & $2.8-14.0$ \\
$\beta$-pinene & $0.4-6.9$ & $1.3-3.5$ \\
(Z)- $\beta$-ocimene & $1.3-5.9$ & 0.0 \\
Sabinene & $0.0-5.0$ & $0.2-10.9$ \\
Camphene & $0.0-4.4$ & $0.0-1.0$ \\
a-pinene & $0.8-4.3$ & $2.7-3.6$ \\
Thujene & $0.9-3.1$ & $1.2-3.4$ \\
a-terpinene & $0.0-2.0$ & $0.5-5.4$
\end{tabular}

Note: BVOCs biogenic volatile organic compounds

Data adapted from Wang, C. T., Wiedinmyer, C., Ashworth, K., Harley, P. C., Ortega, J., Vizuete, W. (2019b). Leaf enclosure measurements for determining volatile organic compound emission capacity from Cannabis spp. Atmos. Environ., 199, 80-87. (Wang et al., 2019b) 
ozone concentrations during the morning and $0.67 \mathrm{ppb}$ at night. Given that Denver county is currently classified as "moderate" non-attainment of the ozone standard (USEPA 2020), the air quality control of the CCF operation is essential.

In addition to BVOC emissions, like every crop cultivation in water-sensitive zones, the fertilization of cannabis causes deterioration in air quality. As fertilization is one of the most critical factors for cannabis cultivation, the introduction of excessive nitrogen into the environment without regulation can lead to adverse multi-scale impacts (Balasubramanian et al. 2017; Galloway et al. 2003). Ammonia in the chemical nitrogen fertilizer volatilized from cropland to the atmosphere forms PM via the reaction with acidic compounds in the atmosphere. Besides, the wet and dry deposition of reactive nitrogen consisting of ammonia continuously deteriorates the ecological environment. Both soil acidification and water eutrophication risks could significantly increase because of the nitrogen cascade (Galloway et al. 2003; Galloway et al. 2008).

\section{Indoor air quality}

Although cannabis can be grown outdoors in many regions of the world, sizeable commercial cultivation can also occur indoors or in greenhouses. Ambient measurements collected inside growing operations pre-legalization have found concentrations as high as $50-100 \mathrm{ppbv}$ of terpenes including $\alpha$-pinene, $\beta$-pinene, $\beta$-myrcene, and d-limonene for fewer than 100 plants in the cannabis cultivation facility (Martyny et al. 2013; Atkinson and Arey 2003; Wang et al. 2019a). The study conducted by Spokane Regional Clean Air Agency (SRCAA) measured indoor VOCs in seven flowering rooms and two dry bud rooms across four different CCFs, reporting the average terpene concentration was $361 \mathrm{ppb}$ (27-1676 ppb) (Southwellb et al. 2017).

Samburova et al. analyzed the BVOCs emissions from four indoor-growing Cannabis facilities in California and Nevada (Samburova et al. 2019). They reported the indoor concentrations of measured BVOCs could vary among the facilities, ranging from $112 \mu \mathrm{g} \mathrm{m} \mathrm{m}^{-3}$ to $5502 \mu \mathrm{g} \mathrm{m}^{-3}$ (Table 3), for a total measured BVOCs of $744 \mathrm{mg}$ day $^{-1}$ plant $^{-1}$. The BVOCs characterization partially agrees with the measurements shown by Wang et al. where $\beta$-myrcene is one of the dominated BVOCs emitted by Cannabis, but eucalyptol was not a dominating terpene in this study (Wang et al. 2019b). The obtained emission rates ranged between 0 to $518.25 \mathrm{mg} \mathrm{day}{ }^{-1}$ plant $^{-1}$. The largest emission contributors were $\beta$-pinene $\left(518.25 \mathrm{mg} \mathrm{day}^{-1}\right.$ plant $^{-1}$, $70 \%$ of the total BVOCs) $\alpha$-pinene $\left(142.92 \mathrm{mg} \mathrm{day}^{-1}\right.$ plant $^{-1}, 19 \%$ of the total BVOCs), and D-limonene (30.86 mg day ${ }^{-1}$ plant $^{-1}, 4 \%$ of the total BVOCs). Silvey (2019) characterized the overall VOC total terpene mass concentration using sorbent tube sampling and found a higher range between $1.5 \mathrm{mg} \mathrm{m}^{-3}$ (office) to $34 \mathrm{mg} \mathrm{m}^{-3}$ (trimming room) (Silvey 2019).

The indoor cannabis (marijuana) grows operations (known as "IMGO") also pose a risk of potential health hazards such as mold exposure, pesticide, and chemical exposure (Martyny et al. 2013). For example, cannabis cultivations typically require a temperature between 21 and $32{ }^{\circ} \mathrm{C}$, with a relative humidity between 50 and $70 \%$ (Koch et al. 2010), while the ventilation rate is often suppressed to limit odor emanating, especially for the illegal cultivation. John and Miller suggested that the houses built after 1980 in Canada are at high risk of moisture-related damage if used as IMGO, and increased moisture levels of the IMGO are associated with elevated mold spore levels (Johnson and Miller 2012). The reports by IOM (IOM 2004) and WHO (World Health Organization) showed that the presence of mold in damp indoor environments is correlated with upper respiratory tract symptoms, respiratory infections, wheeze, cough, current asthma, asthma symptoms in sensitized individuals, hypersensitivity pneumonitis, and dyspnea (WHO 2009). Cuypers et al. conducted a study in Europe, showing that pesticide use in Belgian indoor cannabis cultivation is a common practice, putting both the growers and intervention staff at considerable risk (Cuypers et al. 2017). They

Table 3 Indoor BVOCs concentrations

\begin{tabular}{|c|c|c|c|c|}
\hline BVOCs & Sites & Unit in ppbv & Unit in $u g m^{-3}$ & Ref \\
\hline $\begin{array}{l}\text { a-pinene, } \beta \text {-myrcene, } \beta \text {-pinene, } \\
\text { and limonene }\end{array}$ & Growing room & $50-100$ & n.a & (Martyny et al., 2013; Wang et al., 2019a) \\
\hline Terpenes & Flowering room & $30-1600$ & n.a & (Southwellb et al., 2017; Wang et al., 2019a) \\
\hline Total BVOCs & Growing room & n.a & $112-5502$ & (Samburova et al., 2019) \\
\hline Total BVOCs & Curing room & n.a & $863-1055$ & (Cuypers et al., 2017) \\
\hline Total BVOCs & Purging room & n.a & 1005 & (Trautmann et al., 2012) \\
\hline
\end{tabular}

$B V O C s$ Biogenic volatile organic compounds 
found 19 pesticides in $64.3 \%$ of 72 cannabis plant samples and $65.2 \%$ of 46 carbon filter cloth samples, including o-phenylphenol, bifenazate, and cypermethrin.

\section{Energy demands and carbon footprint Indoor cultivation energy demands and impacts}

As one of the most energy-intensive industries in the USA (Warren 2015), cannabis cultivation results in up to $\$ 6 \mathrm{~B}$ in energy costs annually, accounting for at least $1 \%$ of the nation's electricity (Mills 2012). The cannabis electricity consumption increases to $3 \%$ in California (Warren 2015). In Denver, the average electricity use from cannabis cultivation and associated infused product manufacturing increased by 36\% annually between 2012 and 2016 (DPHE 2018). As cannabis becomes legalized throughout the country, energy consumption will continue to grow in the foreseeable future.

The energy use of indoor cannabis cultivation arises from a range of equipment, falling into two major categories: lighting and precise microclimate control. For the cannabis plants to thrive and therefore make the growers a profit, several energy-intensive tools are regularly utilized. The energy demand for indoor cannabis cultivation was reported to be $6074 \mathrm{kWh} \mathrm{kg-yield}{ }^{-1}$ (Mills 2012). Figure 1 shows the end-use electricity consumption according to a study performed by the Northwest Power and Conservation Council (NPCC 2014). Amongst them, lighting, HVAC (heating, ventilation, and air conditioning), and dehumidification account for $89 \%$ of the total end-use electricity consumption.

High-intensity lighting is the main contributor to electricity for indoor production facilities. Sweet pointed out that lighting alone can account for up to $86 \%$ of the total electricity usage (Sweet 2016). It has been reported that the intensity of the indoor cannabis lamps (25 klux for leaf phase, and 100 klux for flowering (Mills 2012)) approximates that of hospital operating room lamps, which is up to 500 times greater than a standard reading light (Warren 2015). Indoor cultivation facilities typically utilize a combination of high-pressure sodium (HPS), ceramic metal halide $(\mathrm{CMH})$, fluorescent, and/or lightemitting diode (LED) lamps. In addition to the lamp type, lighting system design is also critical to maximizing energy efficiency in the cultivation facilities, and time of use also plays a crucial role.

HVAC Dehumidification system ensures frequent air exchanges, ventilation, temperature, and humidity control day and night. This system can account for more than half of the total energy consumption in an indoor cultivation facility (Mills 2012). Besides, water and energy are inextricably linked, given water and wastewater utilities contribute to $5 \%$ of overall USA electricity consumption (Pimentel and Edwards 1982). The grow systems (including automation and sensors), irrigation (including fertigation and pumps), and $\mathrm{CO}_{2}$ injection also consume an amount of electricity.

Energy production, especially fossil fuel use, is accountable for the environmental impact. Table 4 shows that coal and natural gas make up almost three-quarters of the power supply for Colorado customers in the USA. Considering the environmental impacts of different energy sources, the extensive usages of fossil fuels (coal, natural gas, and oil) causes serious environmental damage and

Table 4 Power supply mix for Colorado customers

\begin{tabular}{ll}
\hline Energy sources & $\begin{array}{l}\text { Total } \\
\text { generation } \\
\text { mix (\%) }\end{array}$ \\
\hline Coal & 44 \\
Natural gas & 28 \\
Wind & 23 \\
Solar & 3 \\
Hydroelectric & 2 \\
Others (including biomass, oil and nuclear generation) & 0
\end{tabular}

Data adapted from Dever Publich Health Environment. 2018. Cannabis Environmental Best Management Practices Guide. (DPHE, 2018)



Fig. 1 End-use electricity consumption 
pose effects on (1) humans, (2) animals, (3) farm produce, plants, and forests, (4) aquatic ecosystems, and (5) buildings and structures (Barbir et al. 1990).

\section{Carbon footprint}

The term carbon footprint refers to "a measure of the exclusive total amount of carbon dioxide emissions that is directly and indirectly caused by an activity or is accumulated over the life stages of a product" (Wiedmann and Minx 2008). In the context of cannabis cultivation, a carbon footprint can be defined as the total amount of greenhouse gases (GHGs) emitted during the production of cannabis. Denver Department of Public Health Environment broke the GHG inventory down into the three primary scopes: (1) an organization's direct GHG emissions produced on-site; (2) an organization's off-site carbon emissions, or indirect emissions; (3) all other indirect carbon emissions associated with the operation of a business (DPHE 2018). However, a relatively small body of literature pays particular attention to the carbon footprint calculation. Mills estimates that producing one kilogram of processed cannabis indoors leads to $4600 \mathrm{~kg}$ of $\mathrm{CO}_{2}$ emissions to the atmosphere, equivalent to one passenger vehicle driven for one year or 11,414 miles driven by an average passenger vehicle (Mills 2012). Amongst them, the emissions factor $\left(\mathrm{kg} \mathrm{CO}_{2}\right.$ emissions per $\mathrm{kg}$ yield) of lighting is 1520 (33\%), followed by ventilation and dehumidify $(1231,27 \%)$, and air conditioning $(855,19 \%)$. On the other hand, outdoor cultivation can alleviate the energy use for lighting and precise microclimate control but requires other facilities and techniques such as water pumping. Carbon footprint analysis is the first step towards the carbon reduction strategies, which contributes to the reduction of the environmental impacts of the cannabis industry. Future studies are foreseen to improve the understanding of the carbon footprint of cannabis cultivation both indoors and outdoors.

\section{Soil erosion and pollution \\ Soil erosion}

Soil erosion is a natural process that occurs when there is a loss or removal of the top layer of soil due to rain, wind, deforestation, or any other human activities. It increases fine-sediment loading into streams and threatens rare and endangered species (Carah et al. 2015). Soil erosion can happen slowly due to wind or quickly due to the heavy rainfall event. Land terracing, road construction, and forest clearing make their ways to remove native vegetation and to induce soil erosion (Carah et al. 2015). Barringer (Barringer 2013) and O'Hare et al. suggested that cannabis cultivation directly contributes to soil erosion (O'Hare et al. 2013). The slope is a useful proxy for erosion potential since soil on steep slopes tends to erosion when cleared or cultivated (Butsic et al. 2018). Butsic and Brenner conducted a systematic, spatially explicit survey for the Humboldt County, California, involving digitizing 4,428 grow sites in 60 watersheds (Butsic and Brenner 2016). About $22 \%$ of the clustered cannabis on steep slopes indicates a risk of erosion. Many studies also suggest that cannabis cultivation can result in deforestation and forest fragmentation (Wang et al. 2017), which exacerbate soil erosion. Though greenhouse prevents soil erosion, they are surrounded by large clearings accumulated during construction with exposed soils subject to erosion (Bauer et al. 2015).

\section{Phytoremediation potential}

Cannabis has gradually garnered attention as a "bioremediation crop" because of its strong ability to absorbing and storing heavy metals (McPartland and McKernan 2017). It can remove heavy metal substances from substrate soils and keep these in its tissues by means of its bio-accumulative capacity (Dryburgh et al. 2018). Usually, it takes up high levels of heavy metals from the soil or growing medium via its roots and potentially deposits into its flowers (Seltenrich 2019). Tainted fertilizer uptake from the soil is often a source of heavy metals contamination such as arsenic, cadmium, lead, and mercury. Singani and Ahmadi reported that Cannabis sativa could absorb lead and cadmium from soils amended with contaminated cow and poultry manures (Singani and Ahmadi 2012). Though limited studies discussed the effectiveness of cannabis for heavy metals removal, many studies have addressed the uptake of heavy metals by industrial hemp (Campbell et al. 2002; Linger et al. 2002). It indicates that the cannabis plant is qualified as a phytoremediation of contaminated soils.

\section{Conclusions and envisions}

A summary of the environmental impacts of cannabis cultivation is shown in Fig. 2. Water demand and usage will continue to be a major concern. Illegal cannabis cultivation and improper operation may raise water pollution issues. Studies on cannabis' physiological properties will guide to determine water demand. Besides, identifying and applying best management practices, such as precision irrigation and enhanced climate control, will be critical to minimize the environmental impacts on water. Energy consumptions mainly come from the equipment operation of the indoor cultivations such as lighting, HVAC, and dehumidification. Carbon footprint can be calculated both indoors and outdoors based on energy consumption. Quantitatively accounting for the energy assumption across operations at scales is the key to better estimating the carbon footprint. Techniques such as life cycle energy 


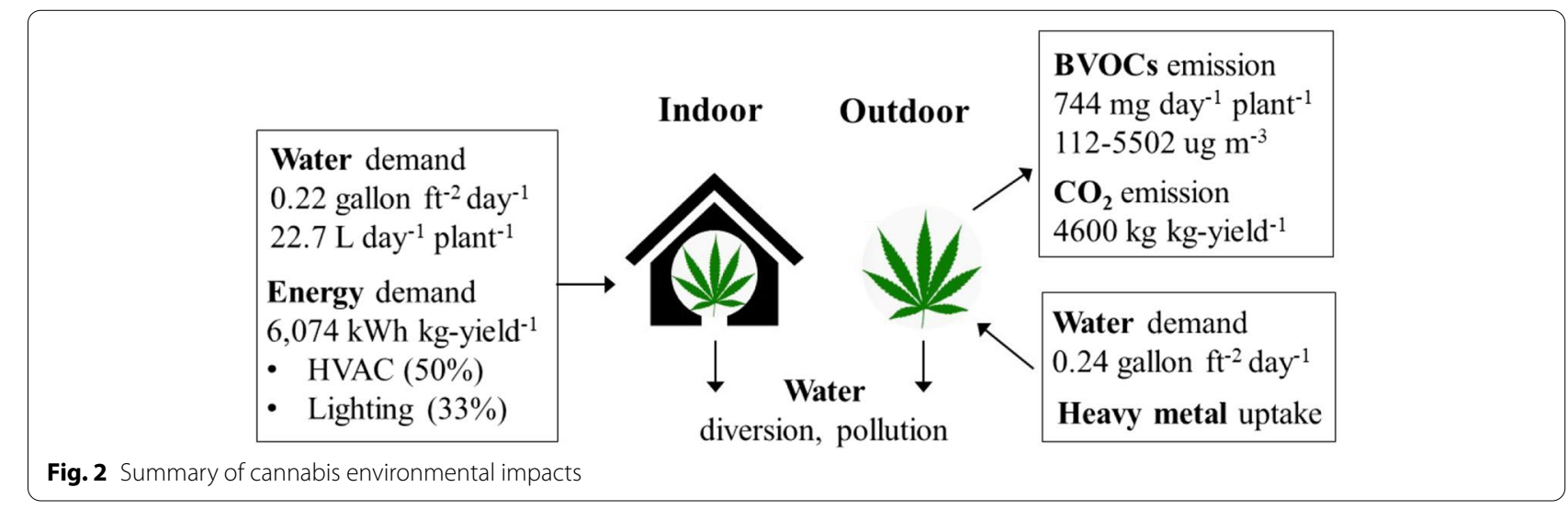

assessment and life cycle carbon emissions assessment would offer informative guidance to reduce the environmental impacts. Few studies have focused on the impacts of cannabis cultivation on air quality. Evidence has emerged that BVOCs and fertilization may contribute to outdoor air quality issues. Indoor air pollutants, i.e., BVOCs emission, mold, pesticide, and chemicals pose a risk of health hazards. Field or chamber studies on determining the species and emission rate of BVOCs, trace gases, and particles from the plant, plant detritus, and soils are important. Much work will be needed to include this information in the emission inventory for air quality modeling. Investigation concerning the contribution of those species to regional, even global air quality, is useful for policymakers and the public. Besides, a better understanding of indoor pollutant concentration and emission ensures the safety of indoor operation. The environmental impact of cannabis cultivation on soil quality has two sides, and it needs to be treated dialectically. On one side, cannabis cultivation directly contributes to soil erosion. On the other side, cannabis has a strong ability to absorb and store heavy metals in the soil. Further studies on the soil mechanics and dynamics of heavy metals in plantsoil interactions are needed.

\begin{abstract}
Abbreviations
ARs: Anticoagulant rodenticides; BVOCs: Biogenic volatile organic compounds; CAMx: Comprehensive Air Quality Model with extensions; CBD: Cannabidiol; CCFs: Cannabis cultivation dacility; CMH: Ceramic metal halide; CSA: Controlled Substances Act; GHGs: Greenhouse gases; HPS: High-pressure sodium; HVAC: Heating, ventilation, and air conditioning; IMGO: Indoor Marijuana Grows Operations; LED: Light-emitting diode; NIH: National Institutes of Health; OSHA: Occupational Safety and Health Administration; PM: Particular matter; SRCAA: Spokane Regional Clean Air Agency; THC: Tetrahydrocannabinols; USDA: Department of Agriculture; VOCs: Volatile organic compounds; WHO: World Health Organization.
\end{abstract}

Acknowledgements

The authors would like to thank Illinois State University for supporting this project.

\begin{abstract}
Authors' contributions
Dr. Zheng worked on sections including outdoor and indoor air quality, energy demand and carbon footprint, and soil erosion. Miss Fiddes worked on water demand and pollution. Dr. Yang supervised Dr. Zheng and Miss Fiddes in completing this project. The author(s) read and approved the final manuscript.
\end{abstract}

Funding

Not applicable.

Availability of data and materials

All data generated or analyzed during this study are included in this published article.

\section{Declarations}

Ethics approval and consent to participate

Not applicable.

\section{Consent for publication}

Not applicable.

\section{Competing interests \\ Not applicable.}

\section{Author details}

'Department of Civil and Environmental Engineering, University of Illinois at Urbana-Champaign, Urbana, IL 61801, USA. ${ }^{2}$ Department of Health Sciences Environmental Health and Sustainability Program, Illinois State University, Normal, IL 61790, USA.

Received: 16 April 2021 Accepted: 9 July 2021

Published online: 06 August 2021

\section{References}

Atkinson R, Arey J. Gas-phase tropospheric chemistry of biogenic volatile organic compounds: a review. Atmos Environ. 2003;37:197-219.

Balasubramanian S, Nelson A, Koloutsou-Vakakis S, Lin J, Rood MJ, Myles L, et al. Evaluation of DeNitrification DeComposition model for estimating ammonia fluxes from chemical fertilizer application. Ag Forest Meteor. 2017:237:123-34

Barbir F, Veziroğlu TN, Plass HJ Jr. Environmental damage due to fossil fuels use. Intern J Hydrogen Energy. 1990;15(10):739-49.

Barringer F. Marijuana crops in California threaten forests and wild life. The New York Times; 2013. https://www.nytimes.com/2013/06/21/us/marijuanacrops-in-california-threaten-forests-and-wildlife.html. 
Bauer S, Olson J, Cockrill A, Hattem M, Miller L, Tauzer M. Impacts of surface water diversions for marijuana cultivation on aquatic habitat in four northwestern California watersheds. PLoS ONE. 2015;10(3). https://doi. org/10.1371/journal.pone.0120016.

Brouwer C, Heibloem M. Irrigation water management: irrigation water needs. Training Manual. 1986;3. http://www.fao.org/3/S2022E/s2022e00.htmv.

Bury RB. Low thermal tolerances of stream amphibians in the Pacific Northwest: implications for riparian and forest management. Appl Herpetol. 2008:5(1):63-74.

Butsic V, Brenner J. Cannabis (Cannabis sativa or C. indica) agriculture and the environment: A systematic, spatially-explicit survey and potential impacts. Environ Res Lett. 2016;11(4):044023. https://doi.org/10.1088/ 1748-9326/11/4/044023.

Butsic V, Carah JK, Baumann M, Stephens C, Brenner JC. The emergence of cannabis agriculture frontiers as environmental threats. Environ Res Lett. 2018;13(12):124017.

Campbell S, Paquin D, Awaya JD, Li QX. Remediation of Benzo[a]pyrene and Chrysene-contaminated soil with industrial hemp (Cannabis sativa). Intern J Phytoremediation. 2002;4(2):157-68. https://doi.org/10.1080/ 15226510208500080.

Carah JK, Howard JK, Thompson SE, Short AG, Bauer SD, Carlson SM, et al. High time for conservation: adding the environment to the debate on marijuana liberalization. Bioscience. 2015;65(8):822-9.

Cuypers E, Vanhove W, Gotink J, Bonneure A, Van Damme P, Tytgat J. The use of pesticides in Belgian illicit indoor cannabis plantations. Forensic Sci Intern. 2017;277:59-65.

Cocker DR, Mader BT, Kalberer M, Flagan RC, Seinfeld JH. The effect of wate on gas particle partitioning of secondary organic aerosol: II. m-xylene and 1,3,5-trimethylbenzene photooxidation systems. Atmos Environ. 2001;35(35):6073-85.

DPHE. Cannabis environmental best management practices guide. Dever Publich Health Environment; 2018. Retrieved January 21, 2020, from https:// www.denvergov.org/content/dam/denvergov/Portals/771/documents/ EQ/MJ\%20Sustainability/Cannabis_BestManagementPracticesGuide_ FINAL.pdf.

Dillis C, Grantham T, McIntee C, McFadin B, Grady K. Watering the Emerald Triangle: Irrigation sources used by cannabis cultivators in Northern California. California Agricul. 2019;73(3):146-53.

Dryburgh LM, Bolan NS, Grof CPL, Galettis P, Schneider J, Lucas CJ, et al. Cannabis contaminants: Sources, distribution, human toxicity and pharmacologic effects. British J Clinical Pharmacol. 2018;84(11):2468-76. https://doi. org/10.1111/bcp.13695.

Elliott JE, Hindmarch S, Albert CA, Emery J, Mineau P, Maisonneuve F. Exposure pathways of anticoagulant rodenticides to nontarget wild life. Environ Monitor Assess. 2014;186(2):895-906.

Gabriel MW, Wengert GM, Higley JM, Krogan S, Sargent W, Clifford DL. Silent forests. Rodenticides on illegal marijuana crops harm wildlife. Wildl Prof. 2013;7(1):46-50.

Gabriel MW, Woods LW, Poppenga R, Sweitzer RA, Thompson C, Matthews SM, et al. Anticoagulant rodenticides on our public and community lands: spatial distribution of exposure and poisoning of a rare forest carnivore. PLoS ONE. 2012;7(7). https://doi.org/10.1371/journal.pone. 0040163.

Galloway JN, Aber JD, Erisman JW, Seitzinger SP, Howarth RW, Cowling EB, et al. The nitrogen cascade. Bioscience. 2003;53(4):341-56.

Galloway JN, Townsend AR, Erisman JW, Bekunda M, Cai Z, Freney JR, et al. Transformation of the nitrogen cycle: recent trends, questions, and potential solutions. Science. 2008;320(5878):889-92.

Gianotti AGS, Harrower J, Baird G, Sepaniak S. The quasi-legal challenge: assessing and governing the environmental impacts of cannabis cultivation in the North Coastal Basin of California. Land Use Policy. 2017;61:126-34.

Goldstein AH, Galbally IE. Known and unexplored organic constituents in the earth's atmosphere. Environ Sci Technol. 2007;41(5):1514-21.

Hood LVS, Dames ME, Barry GT. Headspace volatiles of marijuana. Nature. 1973;242(5397):402-3.

Humboldt Growers Association (HGA). Humboldt County outdoor medical cannabis ordinance draft. 2010. https://library.humboldt.edu/humco/ holdings/HGA2.pdf.

Hussain S, Ahmad A, Wajid A, Khaliq T, Hussain N, Mubeen M. Irrigation scheduling for cotton cultivation. Cotton Prod Use. 2020. https://doi.org/10. 1007/978-981-15-1472-2_5.
Intaboot N. The study of water demand to grow rice in Thailand. 6th International Symposium on the Fusion of Science and Technologies. Jeju; 2017.

IOM. Damp indoor spaces and health. Washington, D.C: Institute of Medicine: National Academies Press; 2004.

Jacob DJ. Introduction to atmospheric chemistry. Princeton University Press; 1999

Johnson LI, Miller JD. Consequences of large-scale production of marijuana in residential buildings. Indoor Built Environ. 2012;21 (4):595-600.

Koch TD, Chambers C, Bucherl S, Martyny J, Cotner J, Thomas S. Clandestine indoor marijuana grow operations- recognition, assessment, and remediation. Fairfax: American Industrial Hygiene Association; 2010.

Linger P, Müssig J, Fischer H, Kobert J. Industrial hemp (Cannabis sativa L.) growing on heavy metal contaminated soil: Fibre quality and phytoremediation potential. Indus Crops Prod. 2002;16(1):33-42. https://doi.org/10. 1016/S0926-6690(02)00005-5.

Marine KR, Cech JJ. Effects of high water temperature on growth, smoltification, and predator avoidance in juvenile Sacramento River chinook salmon. North Am J Fisheries Manag. 2004;24(1):198-210.

Martyny JW, Serrano KA, Schaeffer JW, Van Dyke MV. Potential exposures associated with indoor marijuana growing operations. J Occup Environ Hygiene. 2013;10(11):622-39.

McPartland, J. M., McKernan, K. J. (2017). Contaminants of concern in cannabis: Microbes, heavy metals and pesticides. In Cannabis sativa L.-Botany and Biotechnology (pp. 457-474)): Springer.

Mills E. The carbon footprint of indoor Cannabis production. Energy Policy 2012:46:58-67.

Moyle PB. Inland fishes of California. University of California Berkeley Press; 2002.

NPCC. Electrical load impacts of indoor commercial cannabis production. Northwest Power and Conservation Council; 2014. Retrieved January 21, 2020, from https://www.nwcouncil.org/sites/default/files/p7.pdf.

O'Hare M, Sanchez DL, Alstone P. Environmental risks and opportunities in cannabis cultivation. Report, BOTEC Analysis Corporation, I-502 Project\# 430-5d. Berkeley: University of California; 2013.

Osbeck M, Bromberg H. Marijuana law in a nutshell. West Academic Publishing; 2017

Pimentel D, Edwards CA. Pesticides and ecosystems. Bioscience. 1982:32(7):595-600.

Rice S, Koziel JA. Characterizing the smell of marijuana by odor impact of volatile compounds: an application of simultaneous chemical and sensory analysis. PLOS ONE. 2015;10(12):e0144160.

Rogers D, Aguilar J, Kisekka I, Lamm F. Center povot irrigation system losses and efficiency. Proceedings of the 29th Annual Central Plains Irrigation Conference, Burlington, Colorado. 2017.

Ross SA, EISohly MA. The volatile oil composition of fresh and air-dried buds of Cannabis sativa. J Natural Prod. 1996;59(1):49-51.

Saloner A, Bernstein N. Response of medical dannabis (cannabis sativa L.) to nitrogen supply under long photoperiod. Front Plant Sci. 2020;17. https:// doi.org/10.3389/fpls.2020.572293.

Saloner A, Sacks MM, Bernstein N. Response of medical cannabis (cannabis sativa L.) genotypes to K supply under long photoperiod. Front Plant Sci. 2019;18. https://doi.org/10.3389/fpls.2019.01369.

Samburova V, McDaniel M, Campbell D, Wolf M, Stockwell WR, Khlystov A. Dominant volatile organic compounds (VOCs) measured at four Cannabis growing facilities: pilot study results. J Air Waste Manag Ass. 2019;69(11):1267-76.

Schlenker W, Hanemann WM, Fisher AC. Water availability, degree days, and the potential impact of climate change on irrigated agriculture in California. Clim Change. 2007;81(1):19-38.

Seltenrich N. Cannabis contaminants: regulating solvents, microbes, and metals in legal weed. Environ Heal Perspec. 2019;127(8):082001. https://doi. org/10.1289/EHP5785.

Shiponi S, Bernstein N. Response of medical cannabis (Cannabis sativa L.) genotypes to P supply under long photoperiod: Functional phenotyping and the ionome. Ind Crops Prod. 2021;161. https://doi.org/10.1016/j.inder op.2020.113154.

Silvey B. Characterization of occupational exposure to airborne contaminants in an indoor cannabis production Facility. University of Washington; 2019.

Singani AAS, Ahmadi P. Manure application and cannabis cultivation influence on speciation of lead and cadmium by selective sequential extraction. Soil Sedim Contam: an Intern J. 2012:21(3):305-21. 
Saloner A, Bernstein N. Nitrogen supply affects cannabinoid and terpenoid profile in medical cannabis (Cannabis sativa L.). Ind Crops Prod. 2021;167(1). https://doi.org/10.1016/j.indcrop.2021.113516.

Southwellb J, Wena M, Jobsona B. Spokane Regional Clean Air Agent (SRCAA) Marijuana air emissions sampling testing project. In Inland Northwest Chapter AWMAI, Washington State; 2017.

Sweet SL. The energy intensity of lighting used for the production of recreational cannabis in Washington State and implications for energy efficiency. Evergreen State College; 2016.

Thompson C, Sweitzer R, Gabriel M, Purcell K, Barrett R, Poppenga R. Impacts of rodenticide and insecticide toxicants from marijuana cultivation sites on fisher survival rates in the Sierra National Forest. California Conserv Lett. 2014;7(2):91-102.

Trautmann NM, Porter KS, Wagenet RJ. Pesticides and groundwater: A guide for the pesticide user. 2012. Retrieved from http://psep.cce.cornell.edu/ facts-slides-self/facts/pest-gr-gud-grw89.aspx.

USEPA. 8-Hour ozone (2008) nonattainment areas by state/county/ area. USEPA; 2020. Available at: https://www3.epa.gov/airquality/greenbook/ hncty.html. Accessed 7 Jan 2020.

Wang CT, Wiedinmyer C, Ashworth K, Harley PC, Ortega J, Rasool QZ, et al. Potential regional air quality impacts of cannabis cultivation facilities in Denver Colorado. Atmos Chem Phys. 2019;19(22):13973-87.
Wang CT, Wiedinmyer C, Ashworth K, Harley PC, Ortega J, Vizuete W. Leaf enclosure measurements for determining volatile organic compound emission capacity from Cannabis spp. Atmos Environ. 2019;199:80-7.

Wang IJ, Brenner JC, Butsic V. Cannabis, an emerging agricultural crop, leads to deforestation and fragmentation. Front Ecol Environ. 2017;15(9):495-501.

Warren GS. Regulating pot to save the polar bear: energy and climate impacts of the marijuana industry. Colum J Envtl Lett. 2015;40:385.

WHO. WHO Guidelines for indoor air quality: dampness and mold. Copenhagen:WHO Regional Office for Europe; 2009.

Wiedmann T, Minx J. A definition of "carbon footprint." Ecolog Econ Res Trends. 2008;1:1-11.

Wilson H, Bodwitch H, Carah J. First known survey of cannabis production practices in California. California Agricul. 2019;73(3):119-27.

\section{Publisher's Note}

Springer Nature remains neutral with regard to jurisdictional claims in published maps and institutional affiliations.
Ready to submit your research? Choose BMC and benefit from:

- fast, convenient online submission

- thorough peer review by experienced researchers in your field

- rapid publication on acceptance

- support for research data, including large and complex data types

- gold Open Access which fosters wider collaboration and increased citations

- maximum visibility for your research: over $100 \mathrm{M}$ website views per year

At $\mathrm{BMC}$, research is always in progress.

Learn more biomedcentral.com/submissions 